\title{
The Characteristics of Asphalt Concrete Binder Course (AC-BC) Mixture with Bottom Ash as Aggregate Substitute
}

\author{
Sugiyanto, G..$^{{ }^{*}}$, Harmawan, A. ${ }^{1}$, and Mulyono, B. ${ }^{1}$
}

\begin{abstract}
Highways serve nearly $80-90 \%$ of the population mobility and flow of goods. Utilization of bottom ash, a waste from coal combustion, in highway construction is one of the alternatives to reduce environmental pollution and support Clean Development Mechanism Program of Kyoto Protocol. The aim of this study is to analyze the characteristics of AC-BC mixture that uses bottom ash as partial substitute of fine aggregate and comparing with a standard mixture. Laboratory tests are performed on two different types of mixtures. The tests show that optimum asphalt content for AC-BCstandard mixture is $5.20 \%$ while AC-BCBottom Ash mixture is 5.25\%. Bottom ash has higher porosity along with a little break field and has round shape so that the asphalt absorption is bigger than the crushed stone. Bottom ash can be used as an alternative aggregate to increase the value of flow of the AC-BC mixture, thus converting waste to valuable material.
\end{abstract}

Keywords: Aggregate replacement; asphalt concrete-binder course; bottom ash.

\section{Introduction}

Highways are important transportation infrastructures that influence economy, society, culture, and defense and security. Highways serve nearly $80-90 \%$ population mobility and flow of goods, so that the development of road transport infrastructure is a priority. It is reflected by the amount of national budget absorbed for the construction of new road or maintenance of roads [1]. In the 2014 Indonesian national budget $(A P B N)$, the Ministry of Public Works allocated funds amounting to $\mathrm{Rp} 84.1$ trillion [2]. The impact of this activity is increasing need for both asphalt and natural coarse and fine aggregate. The asphalt is imported as many as 600,000 tonnes per annum. It results in reducing availability of foreign exchange and also diminishing aggregates [3].

The increasing demand for transportation infrastructures, particularly roads, requires appropriate technologies for saving natural resources. Utilization of coal combustion bottom ash waste is one of the alternatives for reducing environmental pollution and supporting Clean Development Mechanism (CDM) program. CDM is regarded as one of the most

${ }^{1}$ Civil Engineering Department, Faculty of Engineering, Jenderal Soedirman University, Л. Mayjend. Sungkono Km. 5, Blater, Purbalingga, Central Java, Post Code 53371, INDONESIA

* Corresponding author; e-mail: gito_98@yahoo.com

Note: Discussion is expected before June, $1^{\text {st }} 2015$, and will be published in the "Civil Engineering Dimension" volume 17, number 2, September 2015.

Received 16 May 2014; revised 20 January 2015; accepted 14 February 2015. important internationally implemented marketbased mechanisms to reduce carbon emissions [4]. Created under the Kyoto Protocol, the CDM was designed to help developed nations meet domestic Green-house Gas (GHG) reduction commitments by investing in low-cost emission reduction projects in developing countries [4,5]. The coal ash can be utilized as building materials such as fly ash cement, mixture of brick, embankment materials, and road pavement material [6]. Fly ash from coal combustion can be used for construstion materials such as embankment, plant roads, reinforced flyover, etc. The usage of fly ash in road works is able to reduce construction cost about 10 to 20 percent [7]. Santosa, et al. [8] evaluated the effect of replacing $10 \%$ to $100 \%$ fine aggregate with bottom ash. The best result was obtained by replacing the fine aggregate by $10 \%$ bottom ash. This replacement could fulfill all requirements except air void. To improve the air void, an additive (chemcrete) should be added. The use of chemcrete increases the stability and improves the air void of asphalt concrete. On the other hand, the growing coal combustion causes problems, especially in the disposal process because it can lead to environmental pollution. It requires efforts and strategies to utilize the coal combustion waste: fly ash or bottom ash for road construction materials to produce high value products and efficient things. One of the strategies is the utilization of bottom ash as an alternative of fine aggregate material in Asphalt Concrete-Binder Course (AC-BC) mixture.

The aim of this study is to determine the optimum bitumen content of AC-BC mixture with crushed 


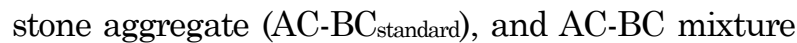
with bottom ash as aggregate substitute (AC$\mathrm{BC}_{\mathrm{Bottom} \text { ash }}$ ) by $20 \%$ and compare the characteristics of $\mathrm{AC}-\mathrm{BC}_{\text {standard }}$ and $\mathrm{AC}-\mathrm{BC}_{\mathrm{Bottom} \text { ash. }}$

\section{Literature}

Asphalt concrete is a construction layer consisting of mixture of asphalt and continously graded aggregate, mixed, spread, and compacted at a specific temperature. Layers of asphalt concrete consists of mixture of three types namely Asphalt ConcreteWearing Course (AC-WC), Asphalt Concrete-Binder Course (AC-BC), and Asphalt Concrete Base (ACBase) with maximum aggregate size of 19, 25.4, and $37.5 \mathrm{~mm}$ respectively [9].

Bottom ash is waste material from coal combustion in power plants with larger size and heavier than fly ash. Bottom ash will fall down onto the bottom of the furnace combustion (boiler). It is collected in dust collector (ash hopper) and then removed from the furnace for specific purposes [10].

Bottom ash and boiler slag have been used with considerable success as fine aggregates in asphalt paving mixtures for at least the past 25 years in different states of the United States. The American Coal Ash Association reported that during 1996 more than 75,000 metric tons (83,000 tons) of boiler slag and nearly 14,400 metric tons (16,000 tons) of bottom ash were used in asphalt paving [11]. A 1994 survey of all 50 state transportation agencies indicated that five states have made some recent use of bottom ash and/or boiler slag as aggregate in asphalt paving on state roadways. These five states are Arkansas, Missouri, Texas, West Virginia, and Wyoming [12]. Dry bottom ash is more commonly used in emulsion cold mix asphalt, hot mix asphalt on the road foundation, rigid pavement or on construction of road shoulders [13].

In West Virginia, United States, the usage of dry bottom ash on flexible pavement on a cold mix asphalt emulsion by $6 \%-7 \%$ of the mass of asphalt emulsion on a secondary road with moderate traffic volumes shows satisfactory results throughout the 1970 's until the 1980's [11]. There have been periodic indications of problems with paving mixtures in West Virginia containing bottom ash, in which pyrite contamination in the bottom ash had not been considered. Pyrite particles will weather in service, despite being coated with asphalt cement, causing popouts, and deep red stains in the pavement surface [11].

In the United Stated, wet bottom ash (boiler slag) is more commonly used for surface layer of asphalt pavement as it is proven to increase roughness (skid resistance). Boiler slag has adhesive (affinity) better to asphalt and it has a dust-free surface. Thereby, it increases the aggregate-asphalt adhesion and resistance to flaking asphalt of aggregates (stripping). Moreover, boiler slag is so black that can not be faded so easily due to sunlight or weather as to reduce the reflection of sunlight and accelerate the melting of snow [13]. For example in West Virginia, USA, it was found that the use of $50 \%$ wet bottom ash, 39\% river sand, 3\% fly ash, and $8 \%$ asphalt for the surface layer with a thickness of 12.7 to $50.8 \mathrm{~mm}$ used as a resurface on the surface layer of asphalt pavement are able to meet the design life of 10 years, with little change in the road surface although it is traversed by heavy vehicular traffic [11]. While in South Texas, the use of wet bottom ash as much as $75 \%$ of fine aggregate mass mixed with $25 \%$ limestone and with bitumen content of $6 \%-7 \%$ to recoat the pavement leads road surfaces to remain in good condition without any shoving, ravelling, and retains roads to be black and rough even they are traversed by heavy vehicles [13]. The other research on the use of bottom ash as construction materials for highway embankments resulted in an economic alternative to the use of traditional materials and test results indicated that ash mixtures compared favorably with conventional granular materials [14].

\section{Materials and Methods}

\section{Materials}

Materials used in this study consist of coarse aggregate, fine aggregate, bottom ash, crushed stone-filler, and bitumen penetration 60/70. The materials used in this study, are shown in Figures 1.a through e.

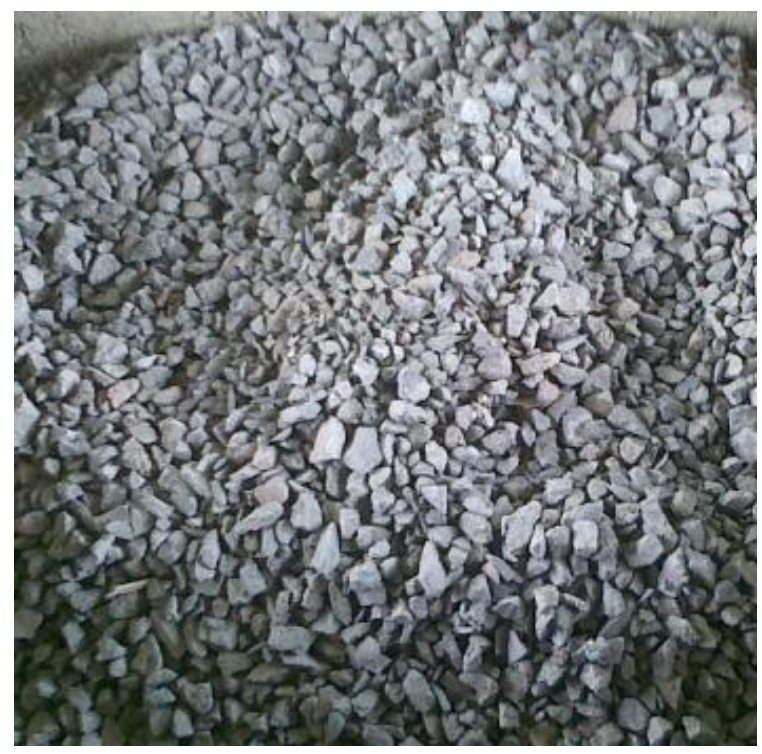

Figure 1a. Coarse Aggregate 


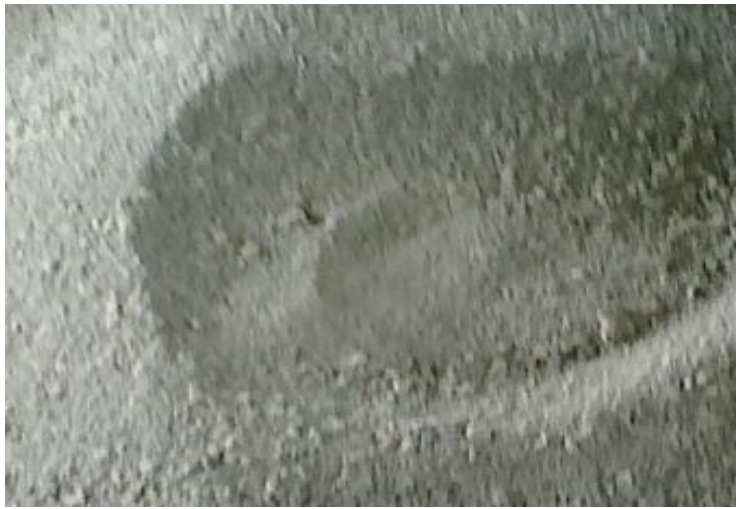

Figure 1b. Fine Aggregate

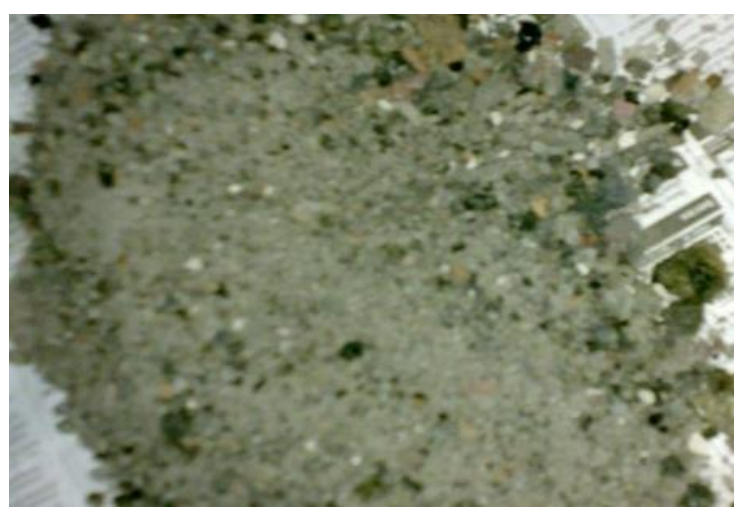

Figure 1c. Bottom Ash

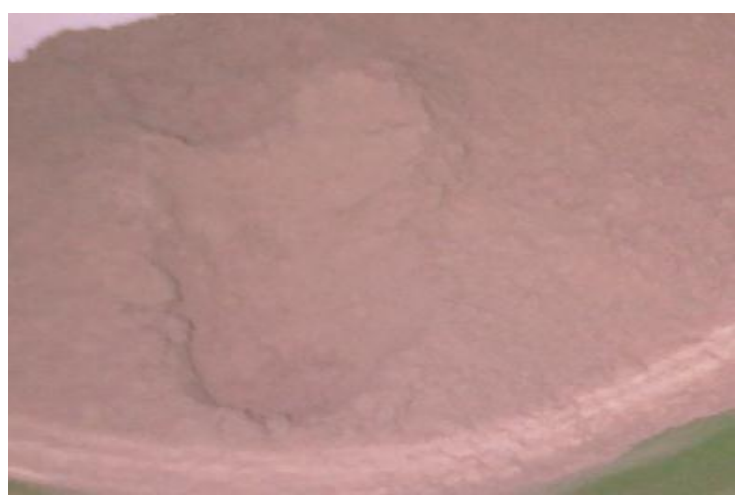

Figure 1d. Stone Ash Filler

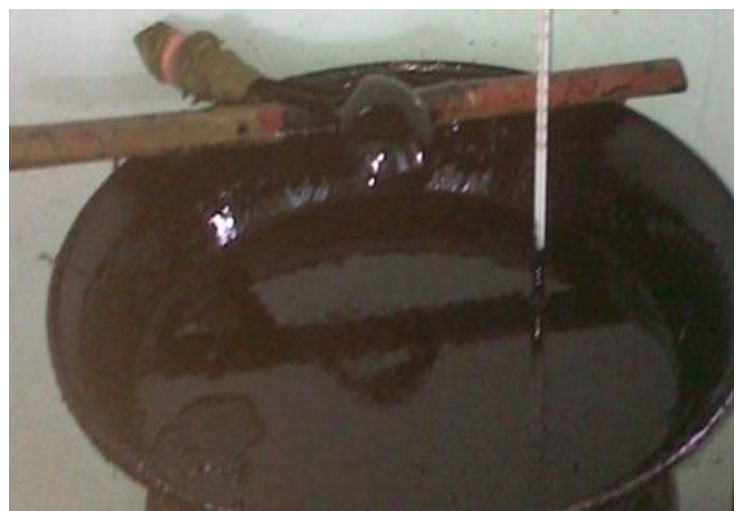

Figure 1e. Bitumen Pen 60/70

\section{Methods}

The method used in this study is an experimental testing in the laboratory. The standards used, are namely the Standard National of Indonesia (SNI) SNI 1969:2008 [15], SNI 2417:2008 [16], SNI 032439-1991 [17], SNI 03-1970-1990 [18], SNI 03-44281997 [19], SNI 03-4142-1996 [20], SNI 06-2456-1991 [21], and ASTM Vol. 04.3 [22]. Hot mixed asphalt was designed with absolute density approach in accordance to the design guidelines of Directorate General of Highways, Ministry of Public Works [23]. The aggregate gradation limit specification followed Bina Marga SKBI 2.4-26.1987 [24]. The total number of samples are 102; i.e. 72 for Stage 1 and 30 for Stage 2. Details of tests and samples of Stage 1 are shown in Table 1 and for the Stage 2 are shown in Table 2.

In Table 2, $\mathrm{X}$ is optimum asphalt content value for AC-BC Standard $_{\text {and }} \mathrm{Y}$ for AC-BC Bottom Ash. $_{\text {. }}$

\section{Results}

\section{Aggregate Testing Results}

Aggregate tests were conducted to determine the characteristics of coarse aggregate, fine aggregate, bottom ash, and filler. The bottom ash was obtained from coal combustion of PLTU Suralaya, Indonesia. The combined aggregate gradation chosen was a mixture of Asphalt Concrete Binder Course, in accordance to the Highways specifications. The physical properties of the coarse aggregate, fine aggregate, filler, and bottom ash [25] can be seen in Tables 3 to 5 .

\section{Asphalt Test Results}

Asphalt test was conducted to determine the characteristics of the material used in the asphalt mixture. Asphalt bitumen was obtained from Pertamina with penetration 60/70. Asphalt test included penetration, softening point, flash and fire point, ductility, specific gravity, and viscosity. Asphalt test results can be seen in Table 6.

Viscosity test was done using Saybolt-Furol with standard test method ASTM E-102 [26]. The data from the viscosity test results, plotted on semilogarithmic graph (relationship between the kinematic viscosities (cSt) with temperature in ${ }^{\circ} \mathrm{C}$, are shown in Figure 2). From Figure 2, the mixture temperature in 170 centistokes is $151^{\circ} \mathrm{C}$ and the compaction temperature in 280 centistokes is $141^{\circ} \mathrm{C}$. 
Table 1. Tests in Stage 1.

\begin{tabular}{|c|c|c|c|c|c|}
\hline \multirow{2}{*}{ No. } & \multirow{2}{*}{ Test } & \multirow{2}{*}{ Mixture type } & \multirow{2}{*}{ Asphalt content (\%) } & \multicolumn{2}{|c|}{ The number of samples } \\
\hline & & & & Number & Total \\
\hline \multirow[t]{18}{*}{1.} & Marshall Test & AC-BCStandard & 4.0 & 3 & 27 \\
\hline & & & 4.5 & 3 & \\
\hline & & & 5.0 & 3 & \\
\hline & & & 5.5 & 3 & \\
\hline & & & 6.0 & 3 & \\
\hline & & & 6.5 & 3 & \\
\hline & & & 7.0 & 3 & \\
\hline & & & 7.5 & 3 & \\
\hline & & & 8.0 & 3 & \\
\hline & & AC-BC Bottom Ash & 4.0 & 3 & 27 \\
\hline & & & 4.5 & 3 & \\
\hline & & & 5.0 & 3 & \\
\hline & & & 5.5 & 3 & \\
\hline & & & 6.0 & 3 & \\
\hline & & & 6.5 & 3 & \\
\hline & & & 7.0 & 3 & \\
\hline & & & 7.5 & 3 & \\
\hline & & & 8.0 & 3 & \\
\hline \multirow[t]{7}{*}{2.} & Absolute density & AC-BCStandard & $\mathrm{P}-0.5 \%$ & 3 & 9 \\
\hline & & & $\mathrm{P}$ & 3 & \\
\hline & & & $P+0.5 \%$ & 3 & \\
\hline & & AC-BC Bottom Ash & $\mathrm{Q}-0.5 \%$ & 3 & 9 \\
\hline & & & $\mathrm{Q}$ & 3 & \\
\hline & & & $\mathrm{Q}+0.5 \%$ & 3 & \\
\hline & \multicolumn{4}{|c|}{ Total number of samples in Stage 1} & 72 \\
\hline
\end{tabular}

Table 2. Tests in Stage 2.

\begin{tabular}{|c|c|c|c|c|c|}
\hline \multirow{2}{*}{ No. } & \multirow{2}{*}{ Test } & \multirow{2}{*}{ Mixture type } & \multirow{2}{*}{ Asphalt content (\%) } & \multicolumn{2}{|c|}{ The number of samples } \\
\hline & & & & Number & Total \\
\hline \multirow[t]{2}{*}{1.} & Absolute density & AC-BCStandard & $\mathrm{X}$ & 3 & \\
\hline & & AC-BC Bottom Ash & $\mathrm{Y}$ & 3 & 6 \\
\hline \multirow[t]{5}{*}{2.} & Marshall & AC-BCStandard & $\mathrm{X}$ (immersion in 30 minutes) & 6 & 12 \\
\hline & immersion & & $\mathrm{X}$ (immersion in 24 hours) & 6 & \\
\hline & & AC-BC Bottom Ash & Y (immersion in 30 minutes) & 6 & 12 \\
\hline & & & Y (immersion in 24 hours) & 6 & \\
\hline & \multicolumn{4}{|c|}{ Total number of samples in Stage 2} & 30 \\
\hline
\end{tabular}

Table 3. Physical properties of Coarse Aggregate: Crushed Stone [25].

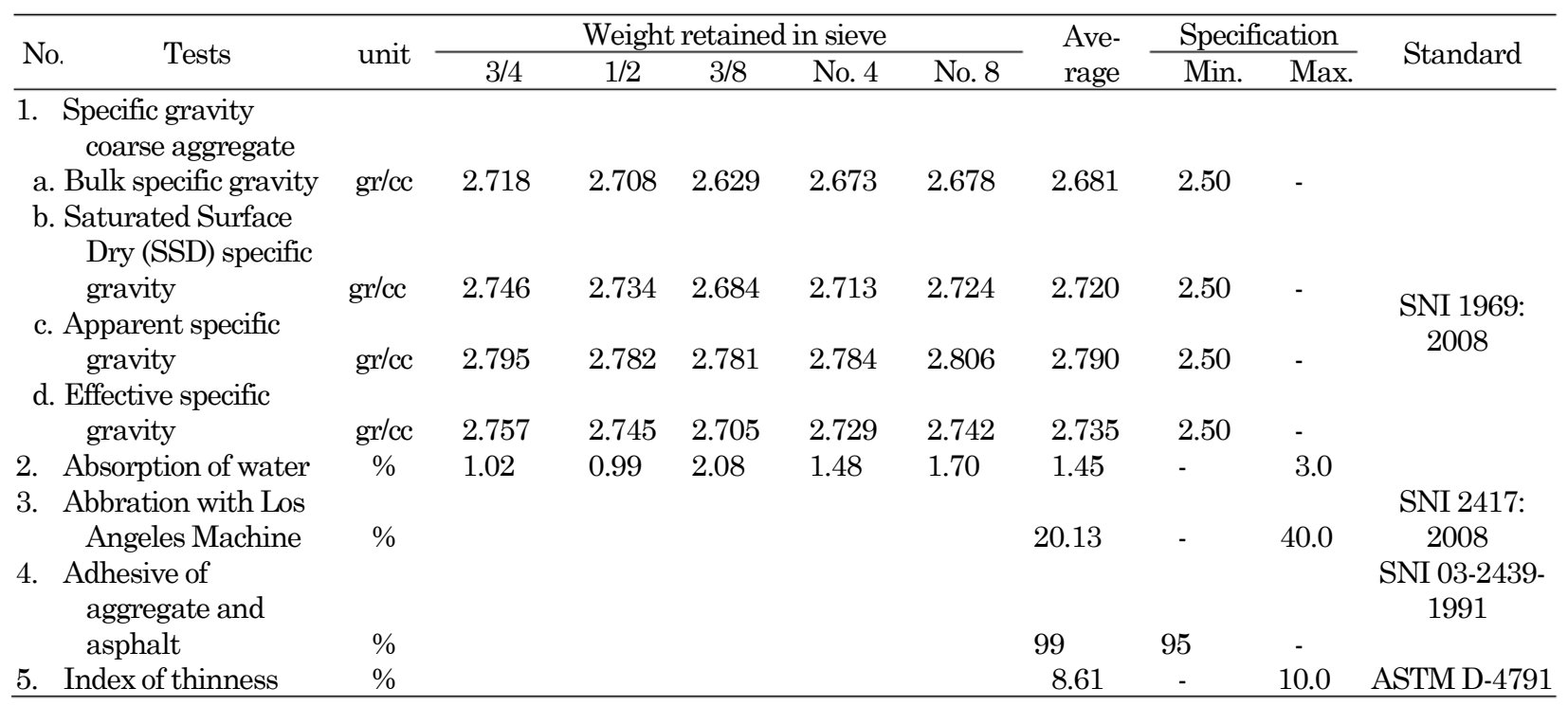


Table 4. Physical Properties of Fine Aggregate and Stone Ash-filler [25].

\begin{tabular}{|c|c|c|c|c|c|c|c|c|c|c|c|}
\hline \multirow{2}{*}{ No. } & \multirow{2}{*}{ Tests } & \multirow{2}{*}{ unit } & \multicolumn{5}{|c|}{ Weight retained in sieve } & \multirow{2}{*}{$\begin{array}{l}\text { Ave- } \\
\text { rage }\end{array}$} & \multicolumn{2}{|c|}{ Specification } & \multirow{2}{*}{ Standard } \\
\hline & & & No. 16 & No. 30 & No. 50 & No.100 & No.200 & & Min. & Max. & \\
\hline \multicolumn{12}{|c|}{$\begin{array}{l}\text { 1. } \quad \text { Specific gravity } \\
\text { fine aggregate }\end{array}$} \\
\hline & $\begin{array}{l}\text { Bulk specific gravity } \\
\text { Saturated Surface Dry }\end{array}$ & gr/cc & 2.809 & 2.725 & 2.733 & 2.737 & 2.726 & 2.746 & 2.50 & - & \\
\hline & (SSD) specific gravity & $\mathrm{gr} / \mathrm{cc}$ & 2.816 & 2.746 & 2.811 & 2.815 & 2.804 & 2.798 & 2.50 & - & SNI 03-1970- \\
\hline c. & Apparent specific gravity & $\mathrm{gr} / \mathrm{cc}$ & 2.831 & 2.783 & 2.964 & 2.968 & 2.957 & 2.901 & 2.50 & - & 1990 \\
\hline d. 1 & Effective specific gravity & $\mathrm{gr} / \mathrm{cc}$ & 2.820 & 2.754 & 2.849 & 2.853 & 2.842 & 2.823 & 2.50 & - & \\
\hline 2. & Absorption of water & $\%$ & 0.28 & 0.77 & 2.86 & 2.84 & 2.86 & 1.92 & - & 3.0 & \\
\hline 3. & Equivalent sand value & $\%$ & & & & & & 45.36 & - & 50.0 & ¡NI 03-4428-199' \\
\hline 4. & Material through sieve & & & & & & & & & & SNI 03-4142- \\
\hline & No. 200 & $\%$ & & & & & & 7.66 & - & 8.00 & 1996 \\
\hline 5. & Specific gravity of filler & $\%$ & & & & & & 2.73 & - & - & $\begin{array}{c}\text { SNI 15-2531- } \\
1991\end{array}$ \\
\hline
\end{tabular}

Table 5. Physical Properties of Bottom Ash [25].

\begin{tabular}{|c|c|c|c|c|c|c|c|c|c|c|c|}
\hline \multirow{2}{*}{ No. } & \multirow{2}{*}{ Tests } & \multirow{2}{*}{ unit } & \multicolumn{5}{|c|}{ Weight retained in sieve } & \multirow{2}{*}{$\begin{array}{l}\text { Ave- } \\
\text { rage }\end{array}$} & \multicolumn{2}{|c|}{ Specification } & \multirow{2}{*}{ Standard } \\
\hline & & & No. 16 & No. 30 & No. 50 & No.100 & No.200 & & Min. & Max. & \\
\hline 1. & $\begin{array}{l}\text { Specific gravity of } \\
\text { bottom ash }\end{array}$ & & & & & & & & & & \\
\hline & Bulk specific gravity & gr/cc & 2.091 & 1.725 & 2.145 & 2.068 & 1.744 & 1.955 & 2.50 & - & \\
\hline & $\begin{array}{l}\text { Saturated Surface Dry } \\
\text { (SSD) specific gravity }\end{array}$ & gr/cc & 2.259 & 2.110 & 2.349 & 2.319 & 2.229 & 2.253 & 2.50 & - & SNI 03-1970- \\
\hline c. & Apparent specific gravity & $\mathrm{gr} / \mathrm{cc}$ & 2.512 & 2.829 & 2.692 & 2.758 & 3.382 & 2.835 & 2.50 & - & 1990 \\
\hline $\mathrm{d}$. & Effective specific gravity & $\mathrm{gr} / \mathrm{cc}$ & 2.306 & 2.277 & 2.419 & 2.413 & 2.563 & 2.396 & 2.50 & - & \\
\hline 2. & Absorption of water & $\%$ & 8.02 & 22.38 & 9.47 & 12.13 & 27.78 & 15.96 & - & 3.00 & \\
\hline
\end{tabular}

Table 6. Asphalt Test Results [25].

\begin{tabular}{|c|c|c|c|c|c|c|}
\hline \multirow{2}{*}{ No. } & \multirow{2}{*}{ Tests } & \multirow{2}{*}{ unit } & \multicolumn{2}{|c|}{ Specification } & \multirow{2}{*}{ Result } & \multirow{2}{*}{ Standard } \\
\hline & & & Min. & Max. & & \\
\hline 1. & Penetration, $25^{\circ} \mathrm{C}, 100 \mathrm{gr}, 5 \mathrm{sec}$. & $0.1 \mathrm{~mm}$ & 60 & 79 & 65 & SNI 06-2456-1991 \\
\hline 2. & Softening point of asphalt & ${ }^{\circ} \mathrm{C}$ & 48 & 58 & 49.50 & SNI 06-2434-1991 \\
\hline 3. & Flash point of asphalt & ${ }^{\circ} \mathrm{C}$ & 200 & - & 285 & SNI 06-2433-1991 \\
\hline 4. & Fire point of asphalt & ${ }^{\circ} \mathrm{C}$ & - & - & 292.50 & SNI 06-2433-1991 \\
\hline 5. & Ductility, $25^{\circ} \mathrm{C}$ & $\mathrm{cm}$ & 100 & - & $>100$ & SNI 06-2432-1991 \\
\hline 6. & Spesific gravity of asphalt & $\mathrm{gr} / \mathrm{cc}$ & 1 & - & 1.038 & SNI 06-2441-1991 \\
\hline \multirow[t]{3}{*}{7.} & Viscosity test in $120^{\circ} \mathrm{C}$ & $\mathrm{cSt}$ & Time: 434 & & 904 & \\
\hline & Viscosity test in $140^{\circ} \mathrm{C}$ & $\mathrm{cSt}$ & Time: 135 & & 283.6 & ASTM E 102-93 \\
\hline & Viscosity test in $160^{\circ} \mathrm{C}$ & $\mathrm{cSt}$ & Time: 52 & & 108 & \\
\hline
\end{tabular}

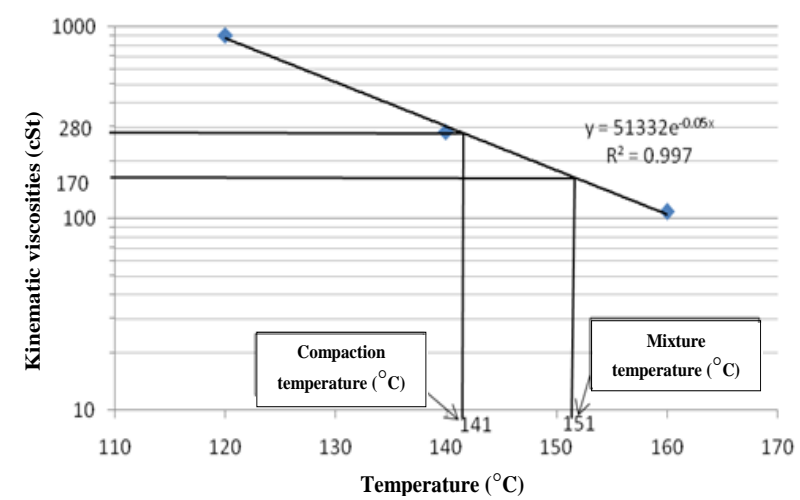

Figure 2. Relationship between the Kinematic Viscosities (cSt) with Temperature $\left({ }^{\circ} \mathrm{C}\right)$.

\section{AC-BC Standard Test Results}

Marshall test and absolute density for each mixture of AC-BCStandard with bitumen/ asphalt content ranges from $4 \%$ to $8 \%$, were measured. There are seven characterictics is Marshall Test: Void in Mineral Aggregate (VMA, \% volume), Void in Mixture (VIM, \% volume), Voids in Mixture refusal

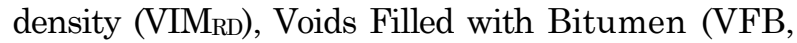
\% VMA), stability, flow, and Marshall Quotient (MQ). Marshall Test results for AC-BC Standard $_{\text {and its }}$ density can be seen in Table 7.

\section{AC-BC Bottom Ash $_{\text {Test Results }}$}

Marshall Test results and absolute density for each mixture of $\mathrm{AC}-\mathrm{BC}_{\mathrm{Bottom}}$ Ash with bitumen/asphalt content ranges from $4 \%$ to $8 \%$ can be seen in Table 8 .

\section{Results of Testing AC-BC Mixture on Opti- mum Asphalt Content}

The determination of the value of optimum asphalt content for the AC-BCStandard and $\mathrm{AC}-\mathrm{BC}_{\text {Bottom }} \mathrm{Ash}$ 
Table 7 Marshall Test Results for AC-BCStandard [25].

\begin{tabular}{|c|c|c|c|c|c|c|c|c|c|c|}
\hline \multirow{2}{*}{$\begin{array}{c}\text { Characteristic } \\
\text { of mixture }\end{array}$} & \multicolumn{9}{|c|}{ Bitumen/asphalt content (\%) } & \multirow{2}{*}{ Specification } \\
\hline & 4.00 & 4.50 & 5.00 & 5.50 & 6.00 & 6.50 & 7.00 & 7.50 & 8.00 & \\
\hline Density $(\mathrm{gr} / \mathrm{cc})$ & 2.359 & 2.379 & 2.399 & 2.419 & 2.424 & 2.429 & 2.434 & 2.421 & 2.417 & \\
\hline VMA (\%) & 16.04 & 15.76 & 15.50 & 15.24 & 15.51 & 15.78 & 16.08 & 16.96 & 17.55 & Min. 14\% \\
\hline VIM (\%) & 8.53 & 7.03 & 5.52 & 4.00 & 3.12 & 2.16 & 1.27 & 1.06 & 0.90 & $3.50-5.50 \%$ \\
\hline $\mathrm{VIM}_{\mathrm{RD}}(\%)$ & & & 4.12 & 2.25 & 1.09 & & & & & Min. $2.50 \%$ \\
\hline VFB (\%) & 46.77 & 55.37 & 64.41 & 73.73 & 79.92 & 86,31 & 92,12 & 93,76 & 94,85 & Min. $63 \%$ \\
\hline Stability (kg) & 1,039 & 1,110 & 1,189 & 1,280 & 1,261 & 1,227 & 1,201 & 1,134 & 1,097 & Min. $1,000 \mathrm{~kg}$ \\
\hline Flow (mm) & 3.90 & 4.11 & 4.28 & 4.45 & 4.60 & 4.62 & 4.77 & 4.83 & 4.92 & Min. 3.00 mm \\
\hline MQ (kg/mm) & 266.4 & 270.2 & 278.0 & 287.6 & 274.4 & 265.7 & 251.8 & 234.9 & 222.9 & Min. $250 \mathrm{~kg} / \mathrm{mm}$ \\
\hline
\end{tabular}

Table 8. Marshall Test Results for AC-BCBottom Ash

\begin{tabular}{|c|c|c|c|c|c|c|c|c|c|c|}
\hline \multirow{2}{*}{$\begin{array}{l}\text { Characteristic } \\
\text { of mixture }\end{array}$} & \multicolumn{9}{|c|}{ Bitumen/asphalt content (\%) } & \multirow{2}{*}{ Specification } \\
\hline & 4.00 & 4.50 & 5.00 & 5.50 & 6.00 & 6.50 & 7.00 & 7.50 & 8.00 & \\
\hline Density (gr/cc) & 2.346 & 2.368 & 2.388 & 2.408 & 2.411 & 2.416 & 2.420 & 2.408 & 2.393 & \\
\hline VMA (\%) & 15.33 & 14.97 & 14.72 & 14.45 & 14.80 & 15.07 & 15.40 & 16.27 & 17.22 & Min. 14\% \\
\hline VIM (\%) & 8.43 & 6.87 & 5.40 & 3.87 & 3.05 & 2.10 & 1.23 & 1.03 & 0.89 & $3.50-5.50 \%$ \\
\hline $\operatorname{VIM}_{\mathrm{RD}}(\%)$ & & & 4.00 & 2.52 & 1.06 & & & & & Min. $2.50 \%$ \\
\hline VFB (\%) & 45.01 & 54.12 & 63.34 & 73.20 & 79.37 & 86.07 & 91.98 & 93.65 & 94.82 & Min. 63\% \\
\hline Stability (kg) & 1,021 & 1,082 & 1,161 & 1,250 & 1,235 & 1,209 & 1,166 & 1,104 & 1,063 & Min. $1,000 \mathrm{~kg}$ \\
\hline Flow (mm) & 4.00 & 4.18 & 4.40 & 4.62 & 4.69 & 4.75 & 4.85 & 4.90 & 4.99 & Min. $3.00 \mathrm{~mm}$ \\
\hline MQ (kg/mm) & 255.5 & 258.6 & 263.7 & 270.7 & 263.1 & 254.5 & 240.5 & 225.3 & 213.0 & Min. $250 \mathrm{~kg} / \mathrm{mm}$ \\
\hline
\end{tabular}

mixture is shown in Figure 3 and Figure 4, respectively. For the AC-BCStandard mixture, the asphalt content that satisfies the three characterictics of Marshall Test: stability, VMA, and flow value, are between $4 \%$ and $8 \%$. The asphalt content that can satisfy all specification of Marshall Test are from 5 to $5.4 \%$. The value of optimum asphalt content of the

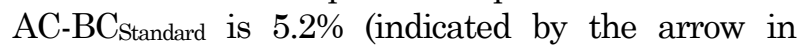
Figure 3). For the AC-BCBottom Ash mixture, asphalt content that satisfies the seven characterictics of Marshall Test and absolute density is between 5\% and $5.5 \%$. The value of optimum asphalt content of the $\mathrm{AC}-\mathrm{BC}_{\mathrm{Bottom}} \mathrm{Ash}$ is $5.25 \%$ (indicated by the arrow in Figure 4).

The comparison of optimum bitumen/asphalt content based on the results of Marshall Test, Marshall Immersion Test, and absolute density AC$\mathrm{BC}_{\text {Standard }}$ and $\mathrm{AC}-\mathrm{BC}_{\text {Bottom Ash }}$ is presented in Table 9.

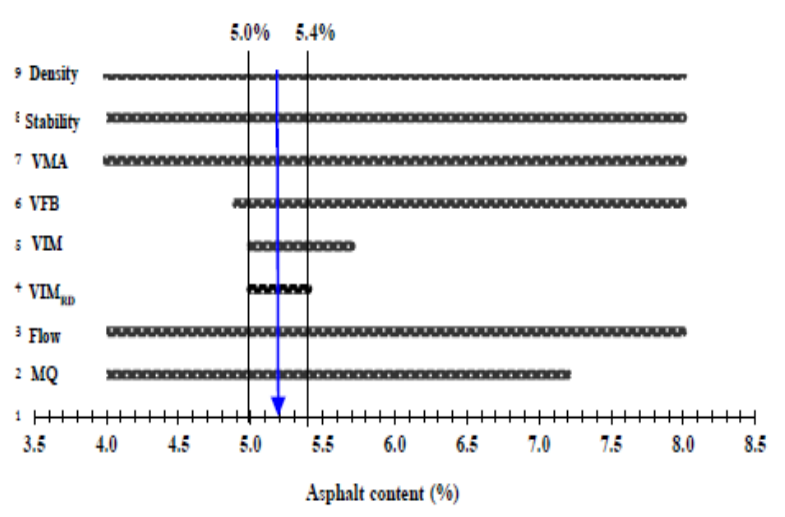

Figure 3. Determination of optimum asphalt content from AC-BCStandard.

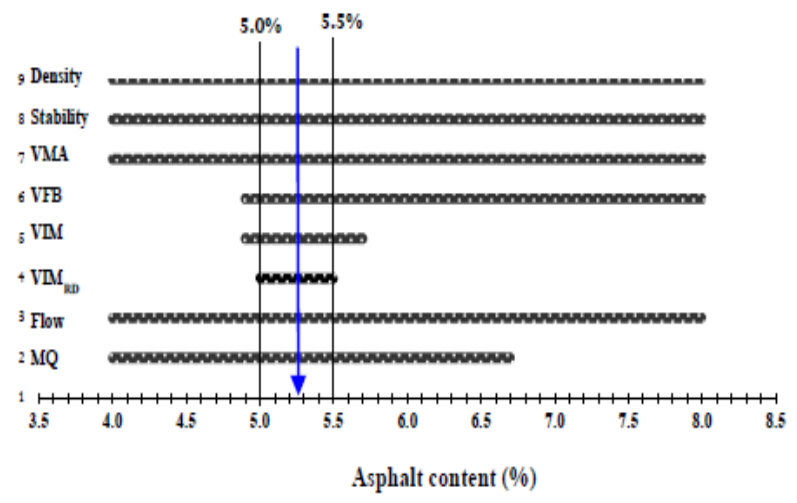

Figure 4. Determination of Optimum Asphalt Content from AC-BCBottom Ash.

\section{Discussion}

Based on the Marshall Test and absolute density of samples (Table 9) the optimum asphalt contents obtained from this study is as follows: optimum asphalt content of AC-BC Standard $_{\text {mixture is } 5.20 \%}$ and of $\mathrm{AC}-\mathrm{BC}_{\mathrm{Bottom}} \mathrm{Ash}$ mixture $5.25 \%$. The density at optimum asphalt content for $\mathrm{AC}^{-\mathrm{BC}_{\text {Standard }}}$ is 2.412 gr/cc whereas for $\mathrm{AC}-\mathrm{BC}_{\mathrm{Bottom}} \mathrm{Ash}$ is $2.397 \mathrm{gr} / \mathrm{cc}$. The larger density values of $\mathrm{AC}-\mathrm{BC}_{\text {Standard }}$ than the $\mathrm{AC}$ $\mathrm{BC}$ Bottom Ash is due to the fact that the crushed stone aggregates have less porosity and low absorption compared to bottom ash. This result is similar to the one reported by Triawan [27] and Yudhianto [28]. The optimum asphalt content with bottom ash is larger than that of crushed stone. The value of optimum asphalt content for the mixture using bottom ash is $13.272 \%$, whereas optimum asphalt content values 
Table 9. Comparison of Optimum Asphalt Content Results AC-BCStandard and AC-BC Bottom Ash

\begin{tabular}{llll}
\hline Characteristic of mixture & AC-BC Standard & AC- BC Bottom Ash & Specification \\
\hline Optimum asphalt content (\%) & 5.20 & 5.25 & \\
\hline Marshall Test (immersion in 30 minutes) & & & \\
Density (gr/cc) & 2.412 & 2.397 & Min. $14 \%$ \\
VMA (\%) & 15.22 & 14.61 & $3.50-5.50 \%$ \\
VIM (\%) & 4.75 & 4.68 & Min. $63 \%$ \\
VFB (\%) & 68.83 & 67.96 & Min. $1,000 \mathrm{~kg}$ \\
Stability (kg) & 1,254 & 1,227 & Min. $3 \mathrm{~mm}$ \\
Flow (mm) & 4.44 & 4.60 & Min. $250 \mathrm{~kg} / \mathrm{mm}$ \\
MQ (kg/mm) & 282.4 & 266.7 & \\
\hline Marshall Immersion Test (immersion in 24 hours) & & Min. $1,000 \mathrm{~kg}$ \\
Stability (kg) & 1,134 & 1,041 & Min. $3 \mathrm{~mm}$ \\
Flow (mm) & 4.13 & 4.10 & Min. $250 \mathrm{~kg} / \mathrm{mm}$ \\
MQ (kg/mm) & 274.5 & 254.1 & Min. $75 \%$ \\
IRS (\%) & 90.42 & 84.91 & \\
\hline Absolute density & & Min. $2.5 \%$ \\
VIM & & \\
\hline
\end{tabular}

for the mixture using natural stone is 6.363\%. Further, the performance of the asphalt concrete mixtures using bottom ash in optimum asphalt content is lower than the asphalt concrete mixtures using natural stone as indicated by Marshall parameters: Marshall Immersion, Indirect Tensile Strength, and Wheel tracking. Generally, bottom ash can be used as partial aggregate substitution of asphalt concrete mixture for road with low traffic [27].

The optimum asphalt contents for Hot Rolled Sheet (HRS) containing bottom ash and HRS-Standard are $16.2 \%$ and $8.4 \%$, respectively. At the optimum asphalt content, the HRS containing bottom ash mixture has lower stability and durability compared to HRS-Standard mixture but it still fullfils the required specification. The performance of HRS containing bottom ash mixture is promising for use as alternative material and should further be developed although based on the economic analysis the utilization of bottom ash for HRS mixture was more costly compared to HRS-Standard [28].

Based on the Marshall test, Voids in Mixture (VIM) value of optimum asphalt content $\mathrm{AC}-\mathrm{BC}_{\text {Standard }}$ mixture is $4.75 \%$, while for the $\mathrm{AC}-\mathrm{BC}$ Bottom Ash mixture $4.68 \%$. The differences of VIM value are due to differences in levels of asphalt content and density values. It is very important to maintain the value of VIM. The VIM value required is between $3.5 \%$ $5.5 \%$ for AC-BC mixture $[9,29]$. The mixture in that range or interval is not susceptible to melting, flowing and plastic deformation [29]. The stability value of optimum asphalt content to $\mathrm{AC}-\mathrm{BC}_{\text {Standard }}$ is $1,254 \mathrm{~kg}$ while one of AC-BCBottom Ash mixture is 1,227 $\mathrm{kg}$. Crushed stone aggregate has abrasion and level of hardness better than those of bottom ash. In addition, the particle shape of bottom ash is round, easily broken, and unfavorable aggregate interlocking making stability of AC-BCBottom Ash mixture lower

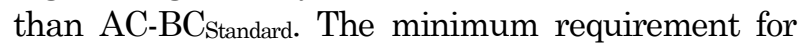
stability value of AC-BC mixture is $1,000 \mathrm{~kg}[9,29]$ so that both mixtures meet the specified requirements. The Marshall Flow test of AC-BCstandard optimum asphalt content is $4.44 \mathrm{~mm}$ while the $\mathrm{AC}-\mathrm{BC}_{\mathrm{Bottom}}$ Ash is $4.60 \mathrm{~mm}$. Bottom ash is more porous than crushed stone aggregate so that bottom ash absorbs the asphalt stronger than crushed stone aggregate does. Specifications of AC-BC flow value is at minimum $3 \mathrm{~mm}[9,29]$. The Marshall Quotient values for AC-BCStandard mixture is $282.47 \mathrm{~kg} / \mathrm{mm}$ and AC-BC Bottom Ash mixture is $267 \mathrm{~kg} / \mathrm{mm}$. AC$\mathrm{BC}_{\text {Standard }}$ mixture is more rigid than the $\mathrm{AC}-\mathrm{BC}_{\mathrm{Bottom}}$ Ash mixture, but still fulfill the specification of Marshall Quotient values AC-BC (minimum 250 $\mathrm{kg} / \mathrm{mm}$ ) [23].

Based on the absolute density test, the value of $\mathrm{VIM}_{\mathrm{RD}}$ of optimum asphalt content for AC-BCstandard mixture is $3.37 \%$ and the value VIM $\mathrm{RD}_{\mathrm{AC}} \mathrm{AC} \mathrm{B}_{\mathrm{Bottom}}$ Ash mixture is $3.28 \%$ because the bottom ash absorbs asphalt more than the crushed stone does and effective volume of asphalt AC-BCstandard is larger than the $\mathrm{AC}-\mathrm{BC}_{\mathrm{Bottom}}$ Ash. The minimum value requirement $\mathrm{VIM}_{\mathrm{RD}}$ for $\mathrm{AC}-\mathrm{BC}$ mixture is $2.5 \%$ [9,29]. The parameters of the Marshall Immersion test are indicated by Index of Retained Strength (IRS). IRS values for AC-BCStandard mixture is $90.42 \%$, while for $\mathrm{AC}-\mathrm{BC}_{\mathrm{Bottom}}$ Ash is as much as $84.91 \%$. The index of retained strength shows that both of the mixture is still able to support the weight. In this case, the property of bitumen in the mixture does not change significantly as a result of oxidation and exfoliation $\left(60^{\circ} \mathrm{C}\right)$. Bina Marga specification for the index of retained strength is minimum 75\% [9], which means that both of the mixture meets the requirements. 


\section{Conclusions}

Conclusions of this study are as follows:

1. The optimum asphalt content value of $\mathrm{AC}$ -

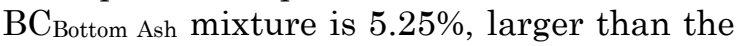
optimum asphalt content AC-BCstandard mixture which is $5.20 \%$.

2. Density, voids in mixture aggregate, voids in mixture, voids filled with bitumen, stability, marshall quotient, voids in mixture refusal density, and index of retained strength of the optimum asphalt content of the mixture of AC$\mathrm{BC}$ Standard are larger than the ones of the mixture of AC-BCBottom Ash.

3. Bottom ash can be used as an alternative material to replace fine aggregate to produce larger flow values compared to the AC-BCstandard mixture.

\section{References}

1. Sugiyanto, G., Kajian Karakteristik Campuran Hot Rolled Asphalt Akibat Penambahan Limbah Serbuk Ban Bekas, Jurnal Teknik Sipil, Universitas Atma Jaya Yogyakarta, Indonesia, 8(2), 2008, pp. 90-103.

2. Kementerian Keuangan, Anggaran Pendapatan dan Belanja Negara (APBN) Tahun 2014. Retrieved on 2014-12-27 http://www.kemenkeu. go.id/sites/default/files/Advertorial\%20APBN\% 202014_061213.pdf.

3. Sjahdanulirwan, M., Pemanfatan Teknologi dalam Peningkatan Peranan Teknik Sipil, Prosiding Seminar Nasional Teknik Sipil, Maranatha Christian University, Bandung, West Java, Indonesia, June 2007, pp. 6-9.

4. Cheng, C., Pouffary, S., Svenningsen, N., and Callaway, M. The Kyoto Protocol, the Clean Development Mechanism, and the Building and Construction Sector-A Report for The UNEP Suistanable Buildings and Construction Initiative, United Nations Environment Programme (UNEP), Paris, France, 2008. Retrieved on 201412-25 http:/www.unep.org/sbci/pdfs/BuildingsandCDMreporte-version.pdf.

5. United Nations Framework Convention on Climate Change (UNFCC). The Clean Development Mechanism. Retrieved on 2014-12-25 http://unfccc.int/kyoto_protocol/mechanisms/cl ean_development_mechanism/items/2718.php.

6. Hermanus, P.A.Y and Lapu, A.S., Perilaku Penggunaan Bottom Ash pada Campuran Aspal Beton. Bachelor Thesis, Petra Christian University, Surabaya, East Java, Indonesia, 2001. Retrieved on 2014-02-15 http://repository.petra. ac.id/3864/.

7. Mattur, S.S. and Vital, S.U.K.G., Utilisation of Fly Ash in Roads and Embankment Works, Geotechnical Engineering Division, Central Road Research Institute, New Delhi, 2009.
8. Santoso, I., Roy, S.K., and Andarias, P., Pengaruh Penggunaan Bottom Ash terhadap Karakteristik Campuran Beton Aspal, Jurnal Dimensi Teknik Sipil (Civil Engineering Dimension), 5(2), 2003, pp. 75-81.

9. Ministry of Public Works, Campuran Beraspal Panas. Buku V Spesifikasi, Seksi 6.3 Spesifikasi Umum Jalan dan Jembatan. Ministry of Public Works, Jakarta, Indonesia, 2006.

10. Turner-Fairbank-Highway Research Center (TFHRC)-Federal Highway Administration. Coal Bottom Ash/Boiler Slag-Material Description, 2000. Retrieved on 2009-10-08 http://www. tfhrc.gov/hnr20/recycle/waste/cbabs1.htm.

11. The Federal Highway Administration (FHWA). User Guidelines for Waste and Byproduct Materials in Pavement Construction. Publication Number FHWA-RD-97-148. Retrieved on 201412-27 http://www.fhwa.dot.gov/publications/ research/infrastructure/structures/97148/cbabs 1.cfm

12. Collins, R.J. and Stanley K.C. Recycling and Use of Waste Materials and By-Products in Highway Construction. National Cooperative Highway Research Program Synthesis of Highway Practice No. 199, Transportation Research Board, Washington, DC, 1994.

13. Turner-Fairbank-Highway Research Center (TFHRC)-Federal Highway Administration. Coal Bottom Ash/Boiler Slag-Asphalt Concrete, 2000. Retrieved on 2009-10-08 http://www. tfhrc.gov/hnr20/recycle/waste/cbabs2.htm.

14. Kim, B., Prezzi, M., and Salgado, R., Geotechnical Properties of Fly and Bottom Ash Mixtures for Use in Highway Embankments, Journal of Geotechnical and Geoenvironmental Engineering, ASCE, 131(7), 2005, pp. 914-924. DOI: 10.1061/(ASCE)1090-0241(2005)131:7(914).

15. Standar Nasional Indonesia (SNI) 1969:2008, Cara Uji Berat Jenis dan Penyerapan Air Agregat Kasar, Badan Standardisasi Nasional (BSN), Jakarta, Indonesia, 2008.

16. Standar Nasional Indonesia (SNI) 2417:2008, Cara Uji Keausan Agregat dengan Mesin Abrasi Los Angeles, Badan Standardisasi Nasional (BSN), Jakarta, Indonesia, 2008.

17. Standar Nasional Indonesia (SNI) 03-24391991, Metode Pengujian Kelekatan Agregat terhadap Aspal, Badan Standardisasi Nasional (BSN), Jakarta, Indonesia, 1991.

18. Standar Nasional Indonesia (SNI) 03-19701990, Metode Pengujian Berat Jenis dan Penyerapan Air Agregat Halus, Badan Standardisasi Nasional (BSN), Jakarta, Indonesia, 1990.

19. Standar Nasional Indonesia (SNI) 03-44281997, Metode Pengujian Agregat Halus atau Pasir yang Mengandung Bahan Plastik dengan cara Setara Pasir, Badan Standardisasi Nasional (BSN), Jakarta, Indonesia, 1997. 
20. Standar Nasional Indonesia (SNI) 03-41421996, Metode Pengujian Jumlah Bahan dalam Agregat yang Lolos Saringan Nomor 200 (0.0075 $\mathrm{mm}$ ), Badan Standardisasi Nasional (BSN), Jakarta, Indonesia, 1996.

21. Standar Nasional Indonesia (SNI) 06-24561991, Metode Pengujian Penetrasi Aspal, Badan Standardisasi Nasional (BSN), Jakarta, Indonesia, 1991.

22. American Society for Testing and Materials (ASTM), Annual Book of ASTM Standard, Vol. 04.03, Road and Paving Material Pavement Management Technology, Philadelphia, 1987.

23. Directorate General of Highways, Pedoman Perencanaan Campuran Beraspal Panas dengan Pendekatan Kepadatan Mutlak, No. 025/T/BM/1999, Direktorat Jenderal Bina Marga, Ministry of Public Works, Jakarta, Indonesia, 1999.

24. Directorate General of Highways (Dirjen Bina Marga), Petunjuk Lapis Aspal Beton (Laston) untuk Jalan Raya/SKBI 2.4-26.1987 UDC: 625.75(02), Yayasan Badan Penerbit Pekerjaan Umum, Ministry of Public Works, Jakarta, Indonesia, 1987.

25. Harmawan, A., Pengaruh Penambahan Bottom Ash sebagai Agregat Pengganti Sebagian pada Campuran Beton Aspal Tipe Lapis Aus-1.
Bachelor Thesis. Civil Engineering Department, Faculty of Engineering, Jenderal Soedirman University, Purwokerto, Central Java, Indonesia, 2010.

26. ASTM E102/E102M-93(2009), Standard Test Method for Saybolt Furol Viscosity of Bituminous Materials at High Temperatures, ASTM International, West Conshohocken, PA, 2009, www.astm.org.

27. Triawan, R., Karakteristik Campuran Beton Aspal dengan Limbah PLTU sebagai Pengganti Agregat Sebagian, Civil Engineering: Transportation Engineering, Magister Program, Bandung Institute of Technology, West Java, Indonesia, 2005. Retrieved on 2014-04-16 www.itb.ac.id.

28. Yudhianto, A., Evaluasi Kinerja Campuran Hot Rolled Asphalt (HRS) yang Mengandung Bottom Ash dan Fly Ash Sebagai Agregat Pengganti Sebagian, Civil Engineering: Transportation Engineering, Magister Program, Bandung Institute of Technology, West Java, Indonesia, 2005. Retrieved on 2014-04-16 www.itb.ac.id.

29. Ministry of Public Works, Pedoman Konstruksi Bangunan No: 001-03/BM/2006, Pemanfaatan Asbuton Buku 3 Campuran Beraspal Panas dengan Asbuton Olahan, Ministry of Public Works, Jakarta, Indonesia, 2006. 